\title{
THE RELATION BETWEEN SLIGHT DIFFERENCE OF NOISE INTENSITY AND AUDITORY FATIGUE
}

\author{
By
}

Toshihiko YOKOYAMA, Shigeto OSAKO, MAsao SUGIYAMA and $\mathrm{K}_{\text {ENICHI HOSHINO }}$

the Department of Oto-Rhino-Laryngology, Osaka City University, Medical School (Directer: Prof. Kaoru Yamamoto)

This paper was attempted to study on the temporary threshold shift (TTS) at $4000 \mathrm{cps}$ by a 20 -min noise exposure through a earphone to each of a subdivided tone, approximately $2 \mathrm{db}$ step, within the range of 79 to 88 phon of white noise. The change of auditory sensitivity was observed by means of Békésy-type audiometer. Nine subjects tested were adult men with normal hearing who had well experienced the Békésy audiometry. These results were as follows:

1) Although the intensities of stimuli of tones were slightly different respectively, a noise intensity which produced a remarked rise of TTS and a prolonged recovery from it was found in all the subjects.

2) A noise intensity level producing of such an elevated threshold was significantly defferent each other :

No. 1 and No. 7 were found at $81 \mathrm{db}$; No. 2 at $82 \mathrm{db}$; No. 3, No. 5, No. 6 and No. 9 at $84 \mathrm{db}$; No. 4 and No. 8 at $86 \mathrm{db}$.

3) Observing the recovery process over a duration of $20 \mathrm{~min}$, the following was noted, that the elevated threshold after stimuli, being recovered to normal threshold, still showed the elevation in $7 \sim 9 \mathrm{~min}$ after stimuli were ceased. This was classified to class IV \& V. These recovery types were more frequently found on 1 grade less intensity of tone than the fatiguing tone intensity producing the remarked threshold shift and prolonged recovery of it. And these recovery pattern dissappeared on the interruped threshold tone at a frequency of $4000 \mathrm{cps}$.

\section{騒音剌戟強度の微小差と NI-TTS (Noise-Induced Temporary Threshold Shift)}

\begin{tabular}{|c|c|c|c|c|c|}
\hline 橫 & 山 & $\begin{array}{l}\text { 俊 } \\
\text { zL }\end{array}$ & $\underset{U=}{\text { 彥 }}$ & $\frac{\text { 迫 }}{\text { 巳゙ }}$ & $\begin{array}{l}\text { 茂 } \\
\text { Lザ }\end{array}$ \\
\hline 杉 & 山 & 正 & 夫・星 & 易 & 健 \\
\hline
\end{tabular}

\section{緒言}

音刺㥂後に出現する一時的聴力損失に関する矿究は， 単に聴覚疲労現象といら病態生理学上の問題としてばか りでなく，騒音性難聴の発生予防に関婵した衛生管理上 の問題として重要視されているので，この研究は従来よ り各方面で行われ，多数の報告がなされている，その一 つとして, Los Angeles の騷音小媝資会の Research Center での Ward き Glorig を中心に進められてい る一時的聴力損失 (TTS) の研究は，実験的に各種の
望響之各様の曝簬条汼での TTS の発生, 回復, 相加 の法則を追求し，訢容度の設定のみならず聴力障害の見 方，管理の実際について子基盤上なる幾つかっの閴題を提 供しょらとしている。

騒音による一時的㯖力椇失は音の強さ，祘波数構成， 曝露時間扣よび曝露様式などの諸因子によつて影響され るが，旮の中音刺钱の強度は最も大きな影響园子である とされている. 白色驧音の実験的発生にはサイラトロン あるいは最近では半導体が応用されているが，これらの 
咩音がランダムノイズであるので，聴覚奏験用の騒音発 生蔆置の出力目盛愔出力の誤差範围を考慮して最小 $5 \mathrm{~dB}$ step になつている.

私達は音刺瀻の強さを的 $2 \mathrm{~dB}$ といら微細な增础なた

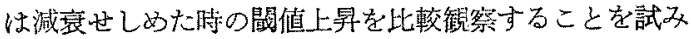
たのであるが，この実験を行った酬機は次の通りであ る.

音響外傷火対する振郵の相加的影響を人体について笑 鮯し初めた頃，騒音曝露にスピーカーを用いていた，即 ち，被检者を振動台上儿直立姿勢で腰掛けさせ，耳孔か ら $1 \mathrm{~m}$ 離れたスピーカーより白色騷音 85 ホン（耳孔部 の位置)が 20 分間儤露 した。 その結果，䮬音に振動 (300 cpm 6 mm または $1000 \mathrm{cpm} 1.5 \mathrm{~mm}$ の上下振動) を添加すると，被榆者は著明な間值上昇を示す者と逆に 闒值に変化をほとえど示さない者に大別され，騷音単独 負荷の時のような一定の傾向がみられなかつた，更に， 同一条件で再測定を行ったところ，その値は，经とんど の例が最初の測定值と著明な相違を示した，これは20 分間の振動被曝中比被検者が無意識の中に，また振動か らのがれようとして上体を側方あるい柱前方に移動し て，スピーカーと耳孔の距離が変り，曝露䪭圧に变化を 生した結果であるうと推察した。

この点を明らか炕するため炕，12 インチの標準型 ス ピーカーの軸上 $1 \mathrm{~m}$ のところに 日本測器慗 SL-7B 型
指示䮣音計のマイクロホンを゙スピーカーに刘して直解化 扣き，その地点(白色騒音 85 ホン) 上り前後方向和上 び各周辺に向けてマイクロホンを 2〜3cm 移動すると 2ホン程度の出力の減弱が認められた。 また別に, 受話 器を用いてスピーカーの時と同一刺战条件で同一被検者 について長期間隔を㨟いて反復測定したところ，スピー カーを用いた時のような著明な変動を示した者は8名中 2名を認めるに過ざなからた。

以上の各実駼成筑から，比較的長時間嚗露であ孔ば， 白色騷音 $85 \mathrm{~dB}$ (ホン) 附近の刺战強度を微小减衰ある いは增強せしめることによつて聴覚疲労の出現侎相にか なりの变化が起り得るのではないかと推測される。ここ に本実踰を行い次のよらな知見を得たので報告する。

\section{実験方法と装置}

1. 羙響曝露方法

受話器（リオン製マスキング用カプラ，約 $700 \mathrm{cc}$ ) に よつて白色馶音を与立た，音刺战強度は受話器の音出力 レベルで表わされた，即ち，音刺㦸の強さの決定は受話 器の皮䖉接触面の位置で R-4 号レシーバーの中心に対 して直角にマイクロホンを策き指示騒音計（日本䉓子測 器製 SL-7B)で行われた。

音刺㦸強度の微小差は下記のような方法で行われた。

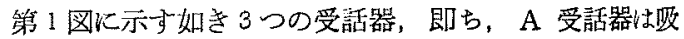

第 1 图 掻音受話器とその周波数特性
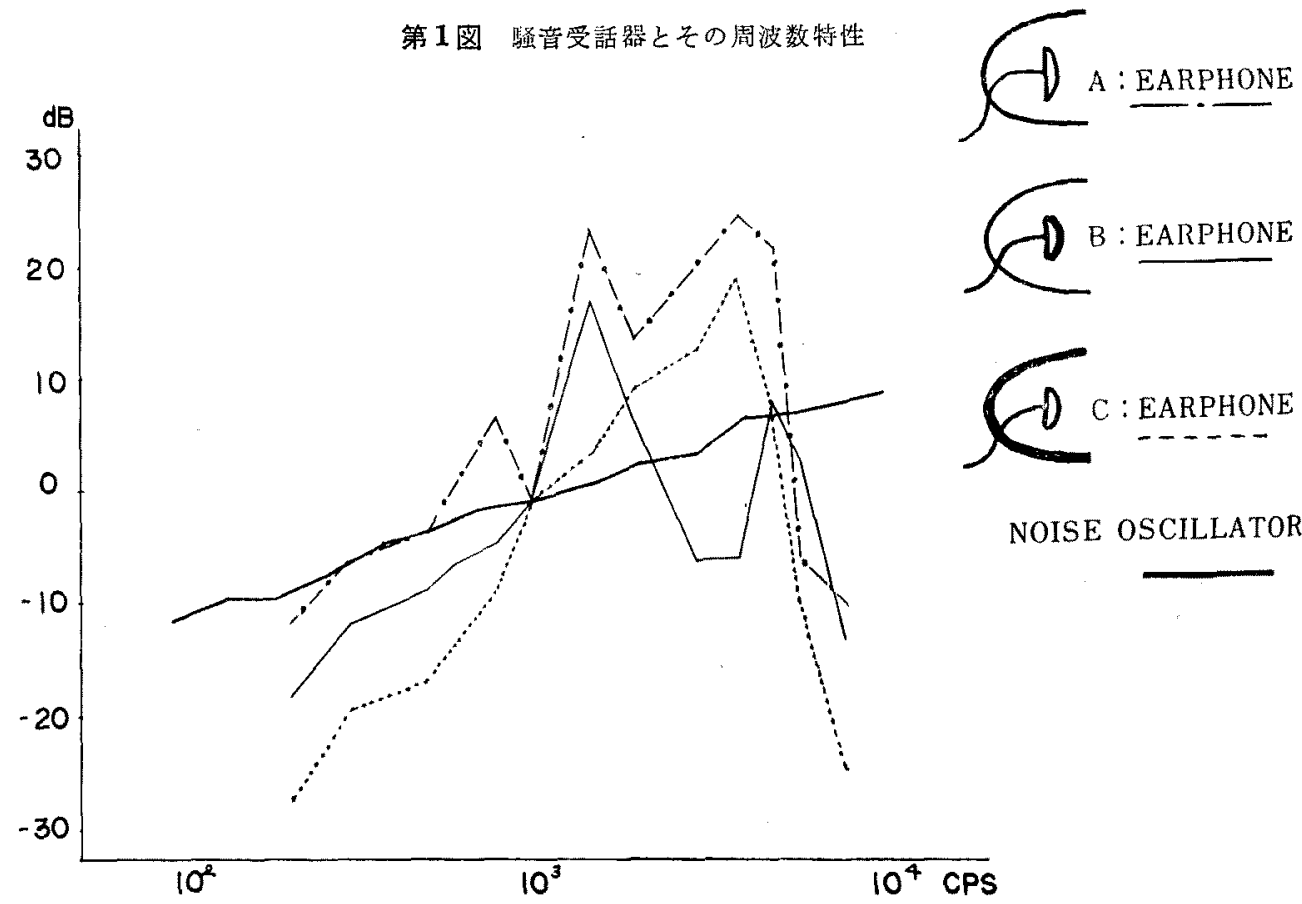

NOISE OSCILLATOR 
音装置のないるの、B 受話器は R-4 号レジーバーの 表面を薄い綿布で被覆したもの，C受話器は受話器 （カプラ）の内壁をフェルト布で覆つたものを用い、こ れらの受話器と騒音発生器の出力目盛との組合せによつ て82ホンから86ホンの間をはぼ 2 phon step に細分 した. A 受話器は 82 ホン音刺㦸に, B 受話器は86ホ ン音刺㦸に，C受話器は84ホン音刺戟に用いられた。 なお，出力音圧は電源電压の変動を受け易すいので，実 験時には山水製自動電圧安定装置によつてその出力の安 定をはからた。 また，ノイズ受話器を被椧耳に密着固定 せしめるために，ヘッドバンドの他に補助バンドが用い て補強した。

本害験使用 した白色騒音発生器および A，B，C の各受話の周波数特性は，第 1 図化示寸通りである、䧴 音空気质導受話器とその試験用カプラの標準化されたも のが末だないので，第 2 図の略図で示すようなカプラを

第 2 图蚵音受話器の周波数特性の測定方法

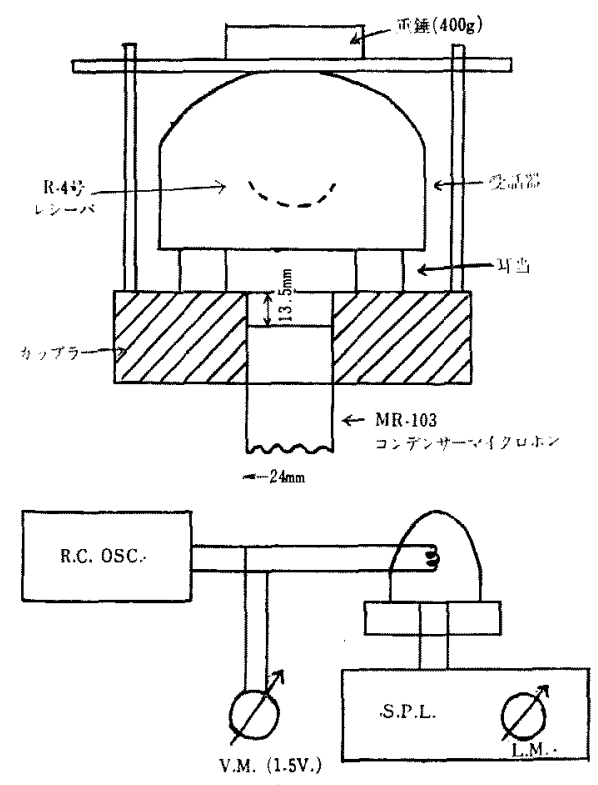

作成して各受話器の特性を求めた， $12 \times 18 \times 4 \mathrm{~cm}$ の整 の木の中央に純音気導音王校正用の標準任力マイクロホ ンがピッタリはまるように穴をあけた，出力音の測定 は上記のカプラの上に受話器をのせ，400g を加えたも のと等しい結合力をもたせてカブラと受話器が気密にな るように固定した，測定周波数を発振器上り発振させ， 発振器の出力を減衰器負荷状態において常に 1.5 Volt
に固定して発振器より出た各周波数の出力を音圧校正器 にて直読した。

\section{2. 测定装置と方法}

音刺战前後の聴覚閾値の測定には，Békésy type $\mathrm{Au}$ diometer（リオン製 A-1014A型）と岩崎製 DR-305 型気導受話器が用いられた。

被検者は聴力正常な男性 9 名で，本大学医学生招よび 医師である．被検耳には右側耳のみが用いられた，被検 者達は Békésy audiometery を今までに何回 む受け て，検查の受け方拉よび检查音をよく理解している者で ある、な拉，連続音閥值描記で著明な順応現象を示ず者 が1名 (No. 5) 含まれている.

検香音には $4000 \mathrm{cps}$ 純音の連繶音が主として用いら

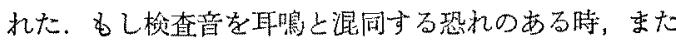
閖值音聴取が不安定であると思われる時，断続音を適時 に聴取せしめた、断続装置にはリオン製 SB-O2 型が 用いられ，锹続音は 4 ips (interruption per second)

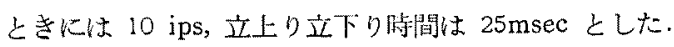
両検查音ともオージオメーターの出力減衰速度は $2 \mathrm{~dB} /$ sec とした.

刺㦸音は白色騒暜 82 ホン, 84 ホン, 86 ホンの3 3 種類

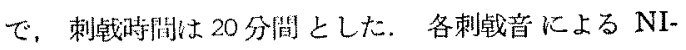
TTS の測定は原則として 1 週間の間隔を拈いて，本大 学の特設防音室で行われた，测定時刻は pm 6.00 9.00 迄とし，1日2〜3人ぶ湘定された。

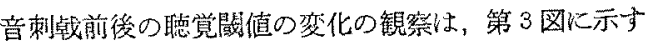
1例のようにして行われた，即ち，先ず，4000 cps 連続 音閔檤は臨床用オージオメーターおよび自記式オージオ メ一ターで求め, 次闌值音描記が 4 分間持続的に行わ れた. 3 4分の休憩の後, 同周波数音で 2 種類の断続 音 (4 ips と $10 \mathrm{ips}$ ) 描記が連続音の場合と同様な方 法で施行された，音刺戟に上る閣値変化は，20分間観 察された。刺㦸停止後 $8 \sim 10$ 秒上り閔值が 4 分間持緛的 に描記され，その後は䦨值音聴取による聴覚順応中聴賞 疲労の增強を防止するために，1分間の休蒩之閶値描記 が交互に行わ秃た。な的，最後の1分間描記（負荷停止 20 分後) の前に 5 分間の休㕷時間が和かれた。

NI-TTS お上びその回復過程の観察項目乙判定基準 は下記の通りである。

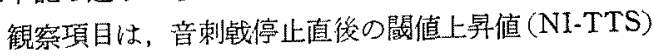
怙よびその後の各测定時点 (5 分， 7 分，11分，13分，

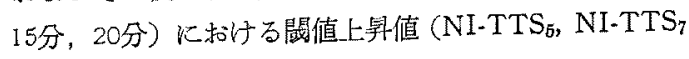
…N.NI-TTS ${ }_{20}$ ), NI-TTS の 20 分間の回復様相，その 
第 3 図 実 测值 の'1 例

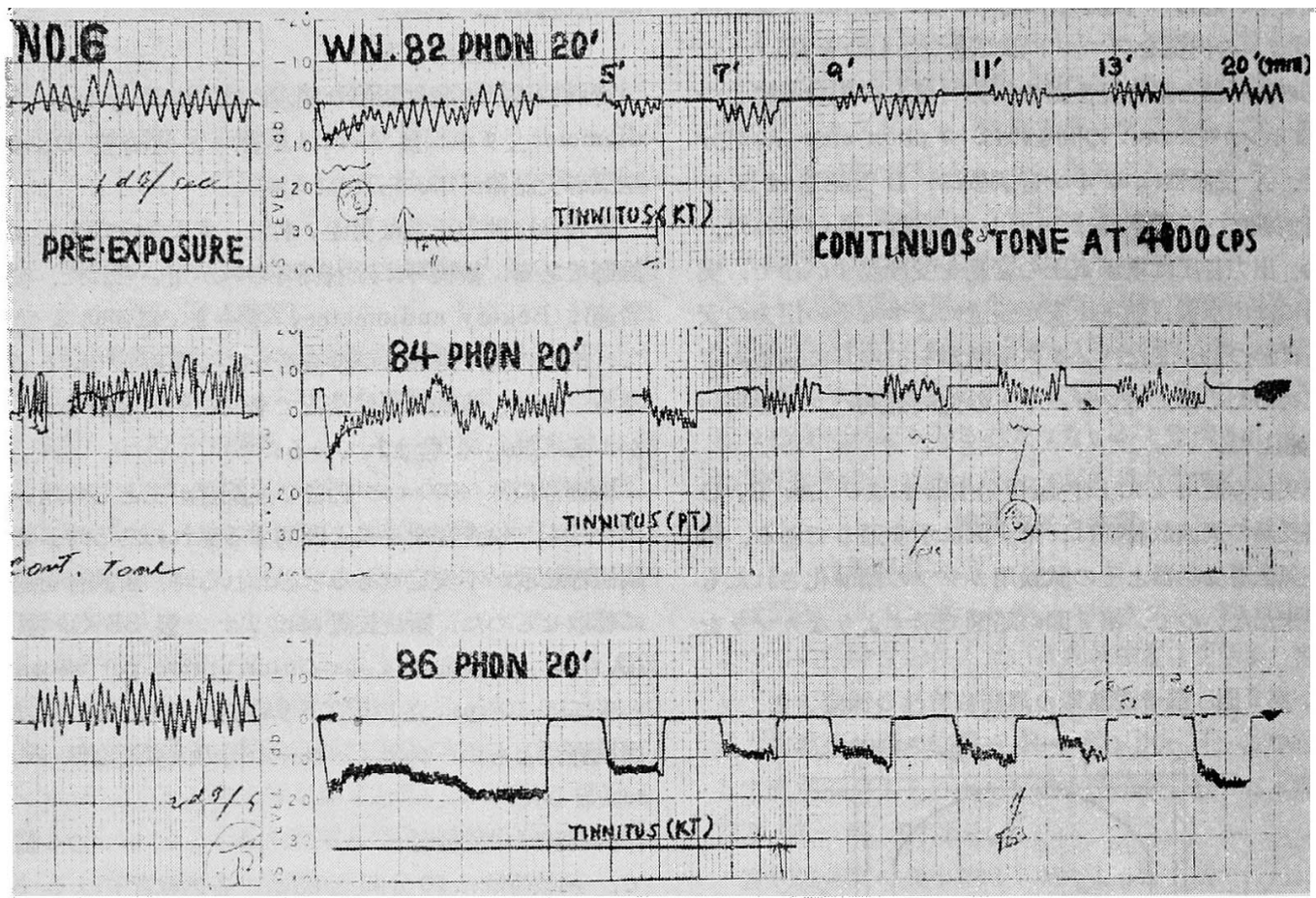

回復時間, 振巾縮小の有無括よび耳鳴の音色と持続時間 である. NI-TTS 值は連続体波の中間点で描記開始か ら 10 秒間の平均値とし, 振巾縮小の有無の判定は音刺 战前後の閾値描記の振巾を主観的に比較して，その程度 により（一)，(士)，(十) に分類した，閾値の回復時間 は負荷前の闇值にほぼ回復した時間であるが，後に述べ るように回復型の N 型および V 型の如く負荷前の闒值に
ほぼ復しても，間值が再び上昇する場合はその一過性の 間值回復時間を本論文では闒值回復時間と仮定した.

\section{実験 結果}

1. 被検者別にみた測定成縝

各被検者の観察項目別成緽は第 1 表に示す通りであ る. 第 4 図の A と B は被険者別に各測定時点に拈け る NI-TTS 值を実線で結んで負荷停止直後の NI-TTS

第 1 表 被 檢者の测定成績

\begin{tabular}{|c|c|c|c|c|c|c|c|c|}
\hline \multirow{2}{*}{ No. } & \multirow{2}{*}{ Phon } & \multirow{2}{*}{ NI-TTS } & \multicolumn{2}{|c|}{ Recovery } & \multirow{2}{*}{$\begin{array}{l}\text { 振巾縮小 } \\
\left(\begin{array}{ll}D & L\end{array}\right)\end{array}$} & 耳 & \multirow{2}{*}{$\frac{\text { 嗎 }}{\text { Time }}$} & \multirow{2}{*}{ ※ } \\
\hline & & & Time & Pattern & & 音 色 & & \\
\hline \multirow{3}{*}{1} & 82 & 14 & 4 & IV & - & ピ - & 4 & $6(7.9)$ \\
\hline & 84 & 18 & $20 \sim$ & VI & \pm & $ヒ^{0}-$ & 11 & $8(5)$ \\
\hline & 86 & 26 & 7 & $\mathrm{VI}$ & + & キーン & 12 & $6(7.20)$ \\
\hline \multirow{3}{*}{2} & 82 & 10 & 4 & $\llbracket$ & \pm & シ - & 3 & $6(11)$ \\
\hline & 84 & 21 & 9 & 】 & \pm & * - & 4 & $10(5)$ \\
\hline & 86 & 18 & 9 & VI & + & キーン & 7 & $3(11)$ \\
\hline \multirow{3}{*}{3} & 82 & 5 & 2 & I & - & ピ - & 13 & 0 \\
\hline & 84 & 5 & 2 & $\mathbb{N}$ & \pm & - & - & $6(5.7)$ \\
\hline & 86 & 12 & $20 \sim$ & VI & $t$ & キーン & 5 & $3(5)$ \\
\hline
\end{tabular}




\begin{tabular}{|c|c|c|c|c|c|c|c|c|}
\hline & 82 & 7 & 2 & N & - & ピ - & 9 & $7(13)$ \\
\hline \multirow[t]{2}{*}{4} & 84 & 6 & 4 & II & \pm & - & - & 0 \\
\hline & 86 & 11 & 4 & II & \pm & - & - & $6(5)$ \\
\hline \multirow{3}{*}{5} & 82 & 5 & 9 & III & \pm & - & - & $6(7 \sim)$ \\
\hline & 84 & 10 & 4 & V & \pm & - & - & 7 (11) \\
\hline & 86 & 20 & 13 & II & + & - & - & $6(9)$ \\
\hline \multirow{3}{*}{6} & 82 & 4 & & 1 & - & $\neq-$ & 5 & $4(7.9)$ \\
\hline & 84 & 12 & 2 & I & - & ピ - & 7 & $6(5)$ \\
\hline & 86 & 17 & $20 \sim$ & VI & + & キーン & 8 & $4(11)$ \\
\hline \multirow{3}{*}{7} & 82 & 13 & 11 & m & \pm & $\div-$ & 4 & $3(5,7,9)$ \\
\hline & 84 & 16 & 20 & II & + & $E^{*}-$ & 11 & $4(5)$ \\
\hline & 86 & 19 & $20 \sim$ & VI & + & *ーン & 12 & $5(9)$ \\
\hline \multirow{3}{*}{8} & 82 & 4 & & 1 & $=$ & 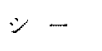 & 6 & $6(20)$ \\
\hline & 84 & 8 & 1 & 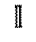 & - & ピ - & 5 & $2(9,11)$ \\
\hline & 86 & 9 & 2 & $\llbracket$ & \pm & $\because \div-$ & 7 & $4(7)$ \\
\hline \multirow{3}{*}{9} & 82 & 8 & 4 & I] & - & シ - & 4 & $5(5,7,9)$ \\
\hline & 84 & 8 & 4 & II & - & $ヒ^{\circ}-$ & 5 & $6(7,11,13)$ \\
\hline & 86 & 19 & 20 & N & \pm & キーン & 5 & $4(5)$ \\
\hline
\end{tabular}

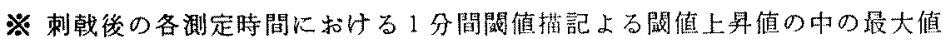
（）内はその测定時間を示す

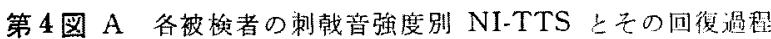
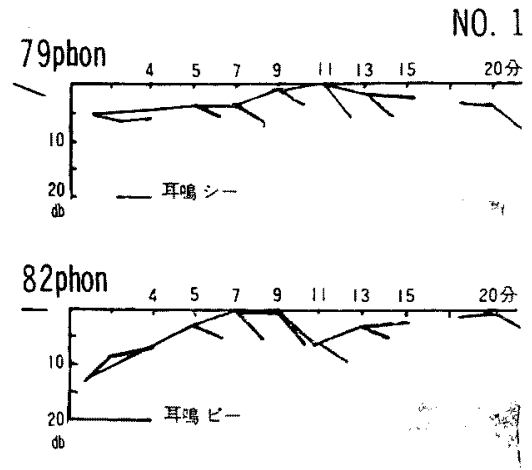

\section{4phon}

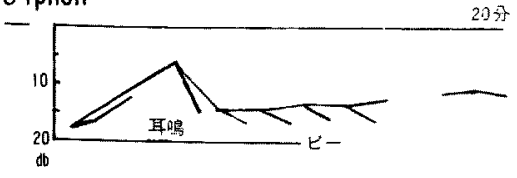

86phon

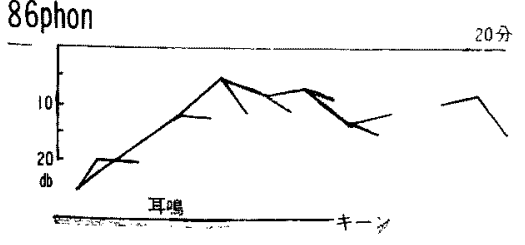

N0. 2
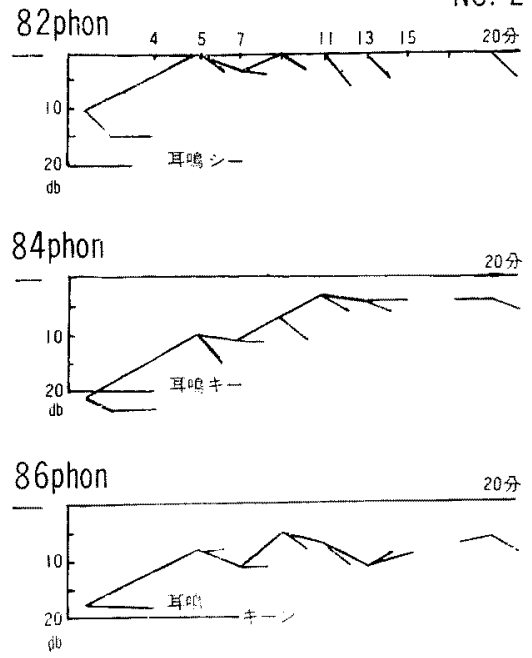
NO. 3
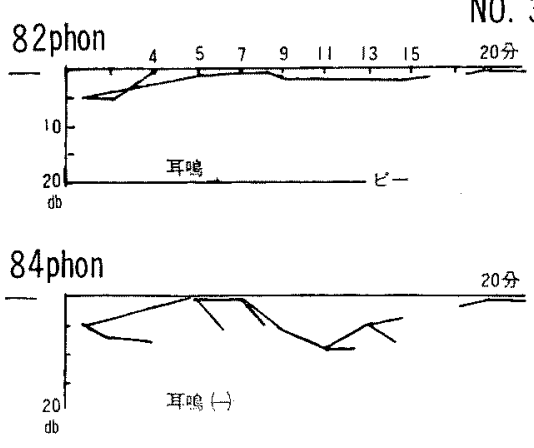

86phon

20 分

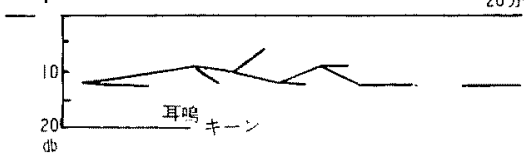

N0. 5
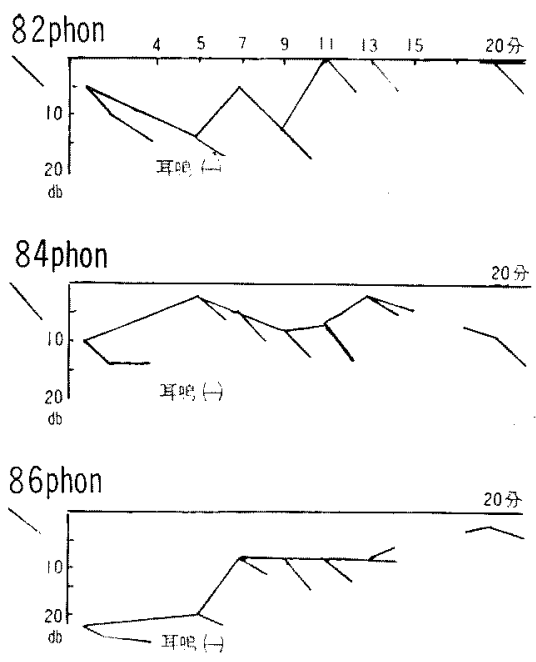

N0. 4
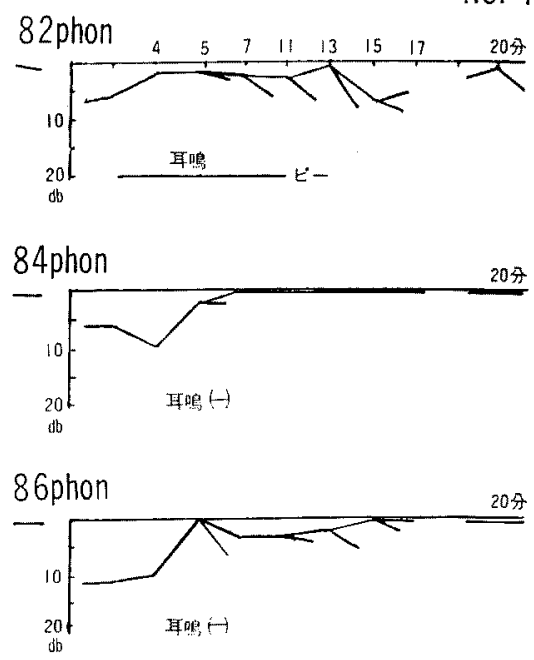

N0. 6
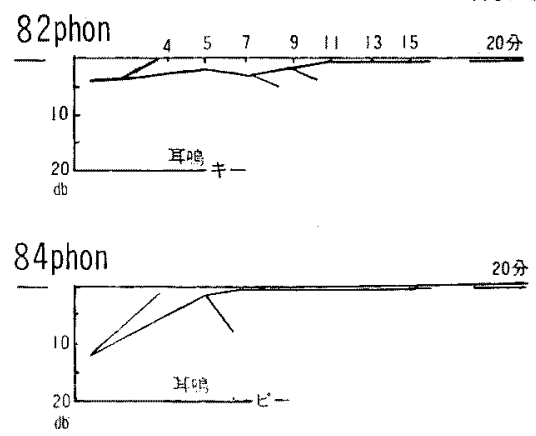

86phon 204

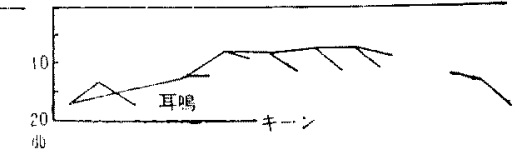

の回復過程を表示し，その下方に音刺㦸で蕧起した耳鳴 の音色とその持続時間を列記した，更に，各測定時点 での $\left(\mathrm{NI}-\mathrm{TTS}_{5} \cdots \cdots\right.$ NI-TTS $\left.{ }_{20}\right) 1$ 分間閾值描記による
闌值上舁（NI-TTS ${ }_{5} \cdots \cdots$ NI-TTS 20 と区别するために $\mathrm{TTS}_{5} \ldots$....TTS $\mathrm{TS}_{20}$ とした）を第 4 図に示す如く直線で表 した. 
第4図 B 各被捈者の刺戟音強度別 NI-TTS と矢の回復過程
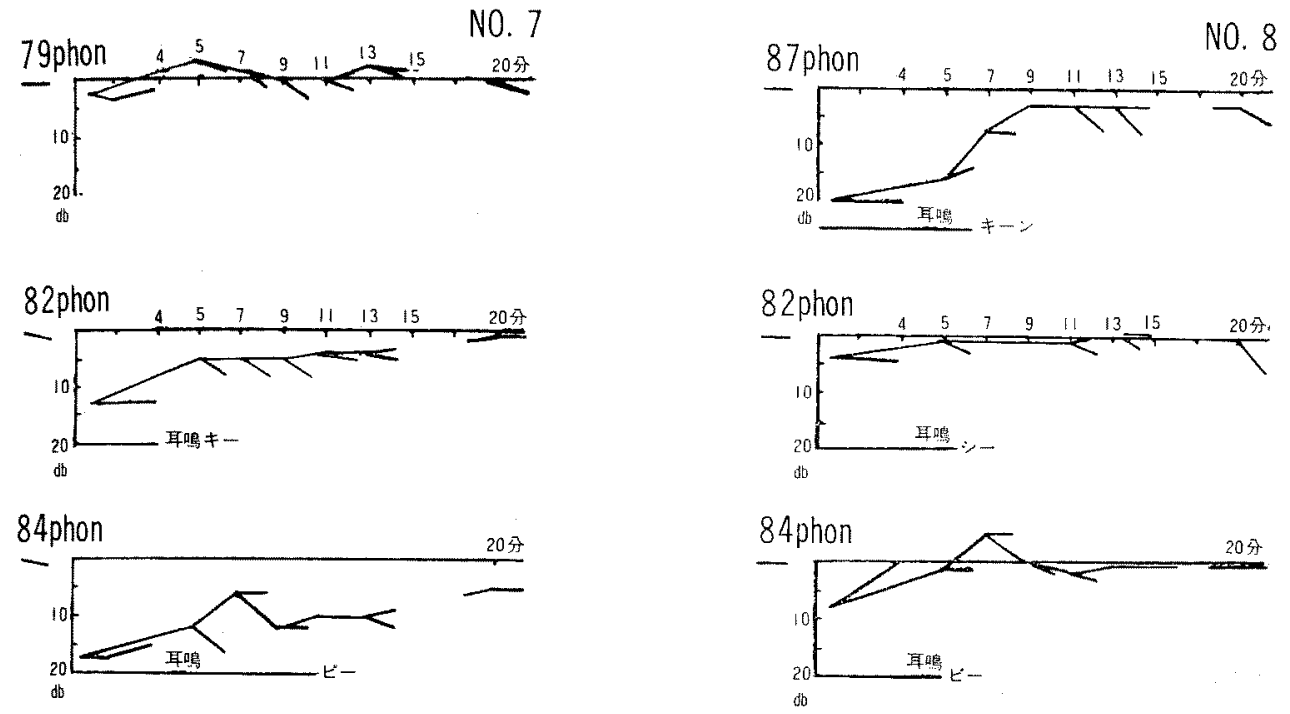

86phon

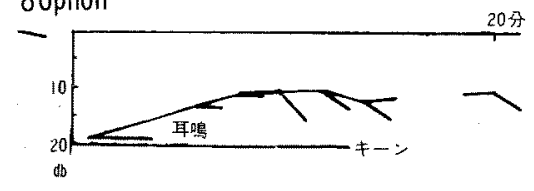

N0. 9
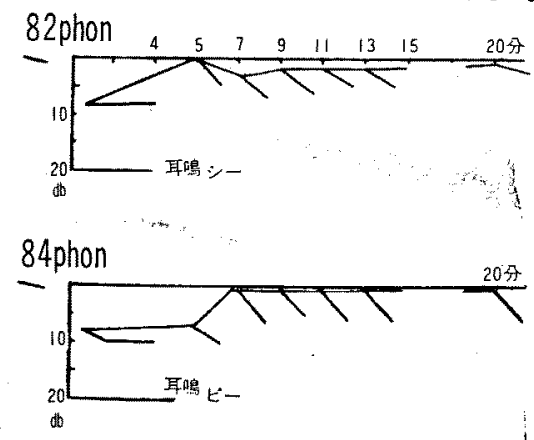

86phon

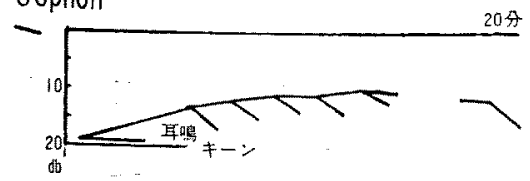

以上の NI-TTS の回復過程の様相は第 5 図に示寸如 く6型に分類された。Ｉ型と【型は音刺㦸中止後 7 分以

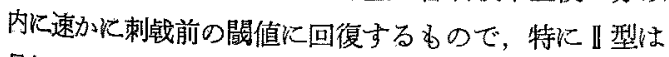
最初の 4 分間の持綕描記中に bounce pensitization

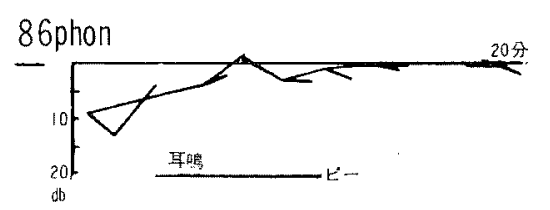

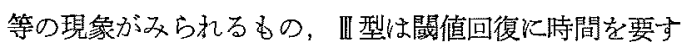

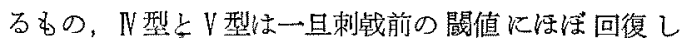
て，再び閾值上等するといら2 相性のパターンを示する の、V型は20 分の観察時間では閶値の回復を示さない ものである。

先ず，No. 1 の被檢者は白色騒音 82 ホンの音刺㦸见 よつて, NI-TTSは14dB となり, 84 ホンで $18 \mathrm{~dB}$, 86 ホンで $26 \mathrm{~dB}$ であつた. 82 ホンによる NI-TTS 值 は第1表をみて理解される如く，他の多くの被検者のそ れ比べて相当に大きいので, 79 ホン（C 型ノイズ受 話器使用) の音刺㦸を行つた。 その結果, NI-TTS は 著明に墄少し $5 \mathrm{~dB}$ 省示した. NI-TTS の回復様相は, 82 ホンで1型，84ホンと86ホンで戊型となつた。耳

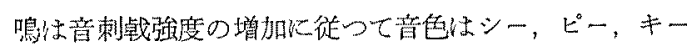
ンの順に低音調から高音調に移行し，その持綕時間も次 第に延長するのが㤮められた。

No. 2 の NI-TTS 值は 82 ホンの刺战強度で $10 \mathrm{~dB}$, 84 ホンで前者の2倍となり $21 \mathrm{~dB}$ を示し， 86 ホンで $18 \mathrm{~dB}$ となつた。䦭值の回復型は 82 ホンでI 型を示し, 84 ホンは细型，86 ホンはV型となり，音刺㦸強度の增 
第 5 图 NI-TTS の回蕧瑟の分類

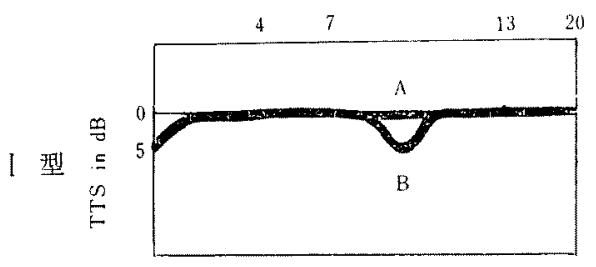

॥ 䍿

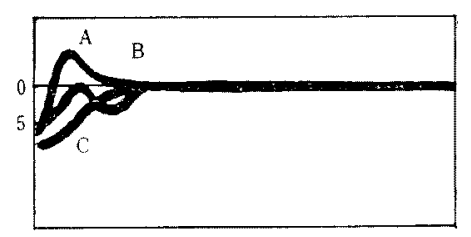

III㻎

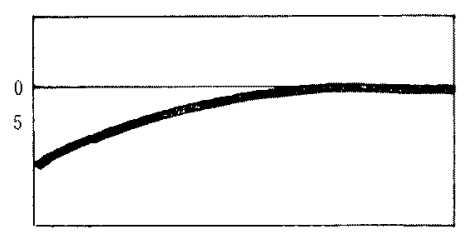

VV 型

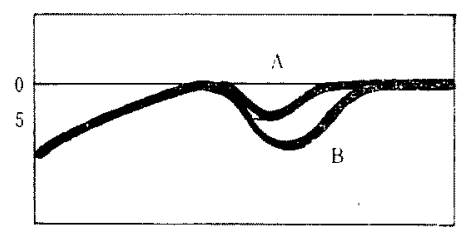

$V$ 型

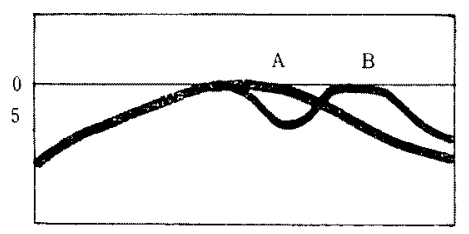

1) 型

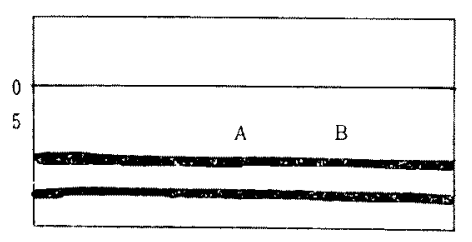

強に比例して閶値回復の延長が明らかにみられた。また

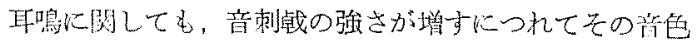

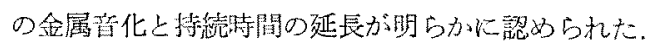

No. 3 は 82 ホン, 84 ホンの刺軲強度では, NI-TTS
の程度は小さく，夫々 $7 \mathrm{~dB}, 6 \mathrm{~dB}$ であり，回復型は前 者は小型，後者はV型であつた。 86 ホンに強めると， NI-TTS は $12 \mathrm{~dB}$ に上昇し，その闦值の回復性は 20 分間の観察洔闌では全くみられなかつた。しかし，耳鳴 の発現状況と音刺钱強度との間になんらの関係が認めら れなかつた. No. 4 は82 ホン，84ホン，86ホンの音 刺戦強度で，は夫 $7 \mathrm{~dB}, 6 \mathrm{~dB}, 11 \mathrm{~dB}$ 々とい5小さな

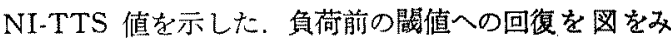
て明らかな如く速かであつた。耳鳴は 82 ホンの刺戟音 で発現しているが，作の 84 ホン，86ホンの場合には耳 鳴忧起らなかつた。 No. 5 の NI-TTS 值は, 音刺戟の 強さ汇等比級数的化增加するのが諗められた，回復型㤌 82 ホンII型，84 ホンV型，86 ホンI型を示した，耳鳴 は全刺战音とも起らなからた。 No.6は82 ホンの刺战 音で $4 \mathrm{~dB}$ という軽度の NI-TTS 值であつたが，84 木 ンでけ前者の3倍の $12 \mathrm{~dB}$ の閔值上算を示した。しか し、84 ホンと86 ホンの刺钱強度の間飞は NI-TTS 值 は大美が認めら机なかつた。，回復型は82ホンでI型， 84ホンで』型，86ホンでり型を示した．耳鳴の発現状況 は音刺㦸強度の增加に比例してその音色の低音調から高 音調への移行と持続時間の延長が明らか䛉認められた. 第3図にその実例を示す通りに，闇值描記の 振巾は 86 ホンの強度で負荷前のそれに比ぺて著明に縮少するのが みられた。

No. 7は前述の No. 1 の成續と同し傾向を示した. 即ち， 82 ホンで $13 \mathrm{~dB}$ の NI-TTS となり，84ホンて $16 \mathrm{~dB}, 86$ ホンで $19 \mathrm{~dB}$ となつた。，閾値の回復様相は82

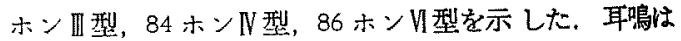
音刺战の強学が増すに従つて, その音色は低音調から高 音調に移行し，その持続時間は明らかに延長することが 認められた，79ホンの音刺㦸試みた結果，因にみら れる如く上記のよらな諸変化侍特に認められなかつた。

No. 8 は, No. 1, No. 7 の場合と異なり，82 ホンか ら86 ホンの閒の音制钱強度では, NI-TTS 值法 $10 \mathrm{~dB}$ 迄であり，刺㦸前の閾値回復も極めて速かであつた：し かし、87ホン ( $\mathrm{A}$ 型)イズ受話器使用)の音刺战を用 いると，図に示宁如く $20 \mathrm{~dB}$ の閶値上昇之金属珄の耳 鳴が発現するのがみられた。

No. 9 は No. 6 と注注同様に 82 ホンと 84 ホンの刺 载強度で怯, NI-TTS は小さく旦つその回復も速いの であるが，86ホンの音刺㥂では NI-TTS 值が $19 \mathrm{~dB}$ となり，回復型はり型を示した，耳鳴音も金属性音に変 つた. 


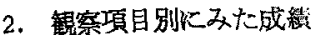

以上の被検者別にみた NI-TTS, その回復過程，耳鳴 についての成樍に加立て，振门縮小の有然，閾值回復時 間を項目別に分けて述へる。

a) NI-TTS：音刺战強度別に各被㭘者をそのバラ メーター(助変数) として夫々の NI-TTS を帮線で結 んで一の図に表示した(第6罒)，各音刺戙による NI-TTS 值の算術平均値ならびにその標準倨差は， 82 ホンの音刺㦸で $7.55 \mathrm{~dB} \pm 3.30 \mathrm{~dB}, 84$ ホンで $11.88 \mathrm{~dB} \pm$ $5.99 \mathrm{~dB}, 86$ ホンで $17.22 \mathrm{~dB} \pm 4.75 \mathrm{~dB}$ となつた。即占。 同一刺战音であつても，得られた測定侹は被検者によつ てかなりの差違がみられるが，音刺㦸强度が微小差であ つてる，各平均攧は刺钱強度の增加に従つて正比例的に 上䄗ることが明らかに㒛められだ

第 6 図 刺戟音強度別の NI-TTS 佰

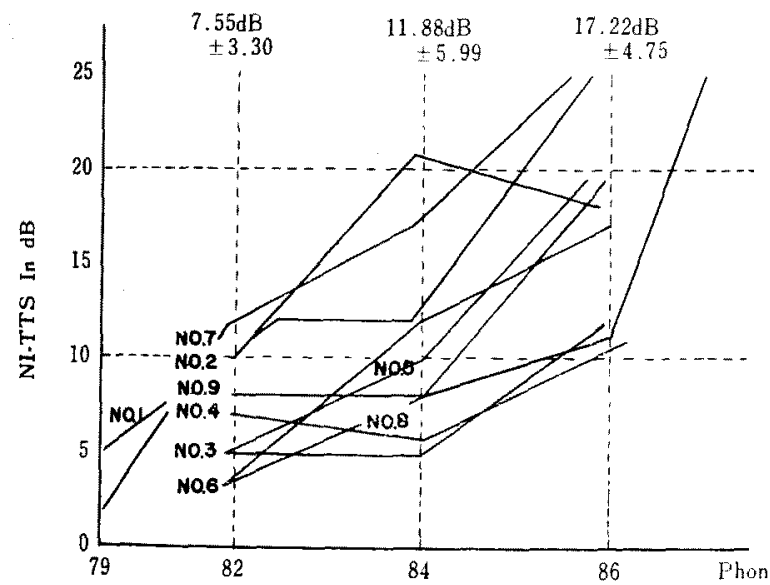

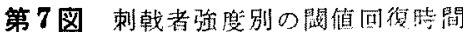

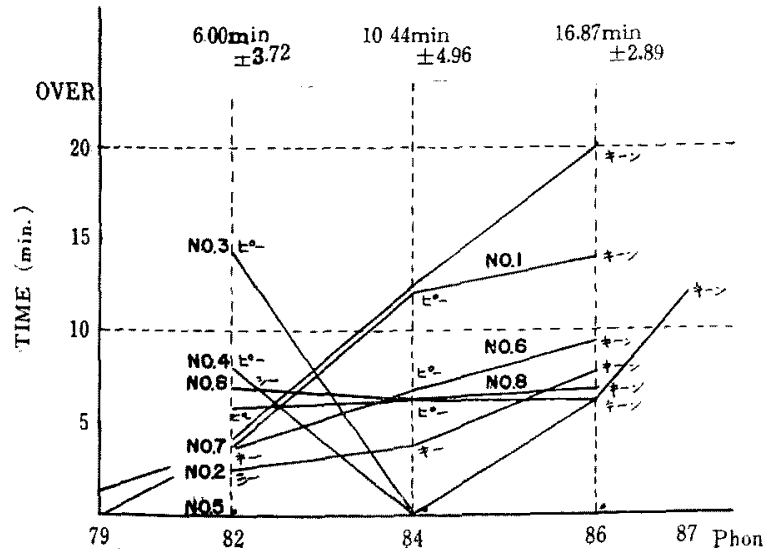

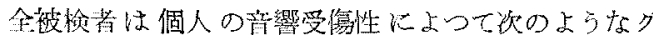
ループに分けb扎。被检者No. 3，No.9は，82 木 ン，84 ホンでは NI-TTS 倠忧跤的小さく大差老認 めないが，86ホン強度を强めると前 2 者の䄪 2 借と いら者明な闍值上昇となつた．No. 2，No. 5 は84ホン

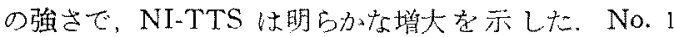
と No. 7 は82 ホンの強さでも NI-TTS 值が他の被枳

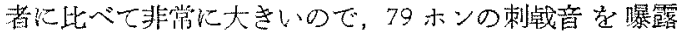
した，乙の絬想，NI-TTS 加急激な減少存示した。 No. 4, No. 8 k, No. I と No. 7 の睍定結果と相反 して，82ホンから86ホンの間の百刺㦸では NI-TTS

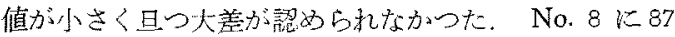

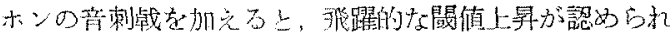
to.

b） NI-TTS の回復時間：第 7 図《上記

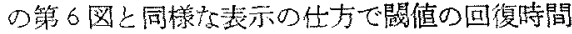
走示したものである。維計学的にみると，82 ホンの刺战強度で $6.00 \mathrm{~min} \pm 3.72 \mathrm{~min}, 84$ ホン で10.44min $\pm 4.96 \mathrm{~min}, 86$ ホンて $16.87 \mathrm{~min} \pm$ $2.89 \mathrm{~min}$ でり，上述の NI-TTS の成就と同 様な傾向放与机た。一船に，NI-TTS の大

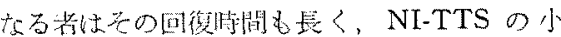
さい诸は问復睏䦌が短くなる便问が多られた。

c) NI-TTS 0 回复様相：各刺㦸音に対 する NI-TTS の回復槏相は第8图に揭示し

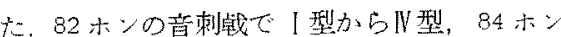
で型からり型とウ広く欢られ，86ホンにな るとその大部分はり型に集中寸るのが認められ た. N型，V型の diphasic pattern ol回傅型 は、82 ホンと84ホンの刺㦸によつてみられ， 86ホンの刺钱強度では現れなかつた

d）振门稚小の有然：穴刺㦸による閾值描 記の振巾小の出現（DL と示吉）は，上述の回

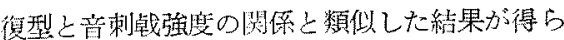
れた（第 8 因）。即ち，音刺战强度の增強に徒 つて振巾縮小の傎问が友られ，86ホンの強さ に商わると，被检者の殆んどが明らかな报維 小を示した，特に，音刺軲中止後 4 分閆で刺战

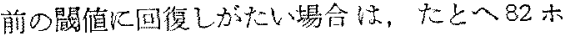
ソ，84 ホンの剩战音であつても間值描記の振

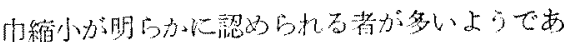
Dto

e）耳鳴の快況：耳鳴の出現は，第9龱を 
第 8 図刺韩音強度別の闘值回復型と振门維小

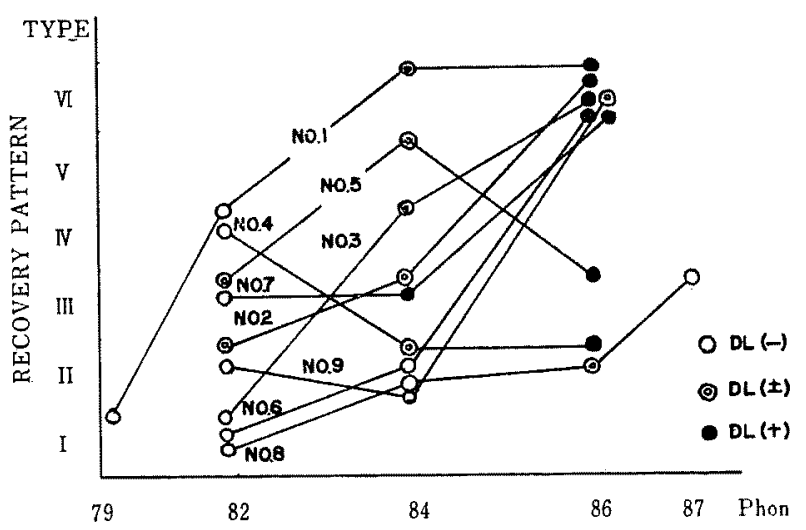

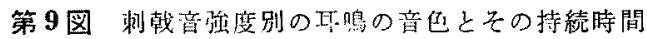

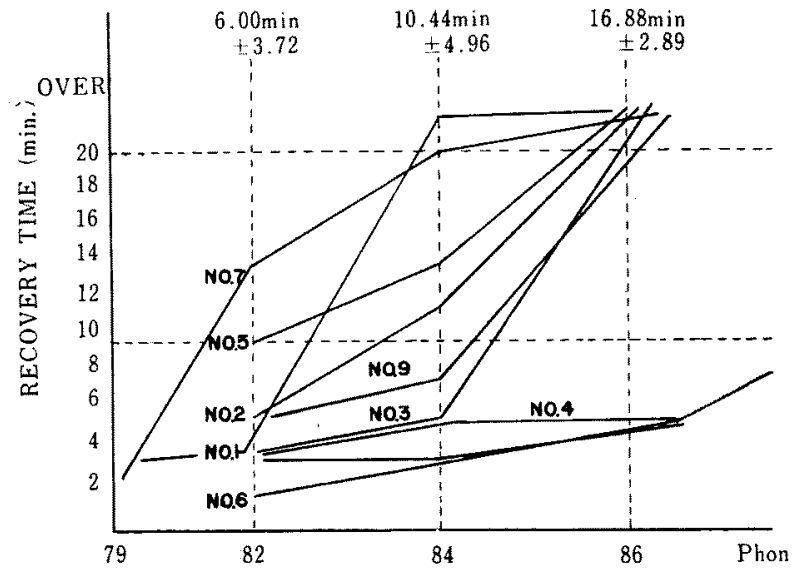

疲労”之総称されているが，各研究者によつて まちまらな名称がつけられ定義されている，例 えば, residual masking (Munson and Gardner; 1950) 19), post-stimulatory fatigue (Hood; 1950) ${ }^{12}$, reversal acoustic trauma (Jerger；1956) 18) などがある.Van Dishoeck (1953) 4) は閾值の回復の長短によつて, 疲学々㯰觉順応に分け，両者は别の機転によつ て起るとし，Rüedi (1954) 24) は前者を病的 疲学，後者を生理的疲労と呼ん犬。. Schaefer (1960) ${ }^{26)}$ は以上の聴覚疲労現象を単に fatigue (Ermüdung) と乎んでいる. Weber (1949) ${ }^{35)}$ は閾値の回復に数日を要する場合, stimulation deafness といら術語を用いてい 3.

しかし，これらの術語の間には，明らかにを の術語の定義を区別する明確な定義悓在まだ 確立されていない上らである. Reger and Lierle (1954) 22) は疲労とか心順応とか心 術語 を避けて，周值変愽 Temporary Threshold Shift (TTS) 年用いた。最近, Glorig et al $(1961)^{7) 20)}$ は間値上一定の強さの音刺战停止 後に出現する閾值上昇を特に Noise-Induced TTS (NI-TTS) と呼び，間值レベルの持続

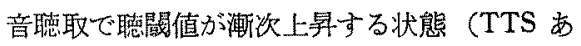
るい、 threshold adaptation) と区別した。私

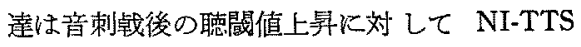
を使用するのが現段階において最る合理的な用 語と教え，本諭文に沽いてはこれに從つた。

锶器の疲労に影響するものとして, Schaefer ${ }^{26)}$ は負 荷騒音の音圧, 周波数構成, 負荷洔間, 閾値測定の時 期，検查音の周波数怙よびその提示時間の6つの因子が あると述べているが，しかし，一般には艺の中でも刺戱 望の强さが最本大きな影響因子であるといわれている。

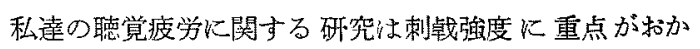
れ，特に刺钱強度別の差が僅小差で行われていることが 從来の矿究之異なる点で方る。广小方, broad-band noise の82 ホンから86ホンの間を居 2 phon step に細分して，それぞれの刺㦸音を受話器を介して20分 閒曝露した後の NI-TTS とその回愎過程を観察したも のである。

通常，騷番刺钱の㢾度差小最小 $5 \mathrm{~dB}$ 間隔である。こ

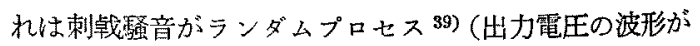

\section{総括および考按}

音刺㦸後に出現する一時的聪力損失は一般に“㯖覚 
不规則化变動する要素を含む波形で表わされる事象）で あることから，音出力の詰差範围は $10 \mathrm{~dB}$ ，最低 $7 \mathrm{~dB}$ 以内であるとされている88)。しかし，たとえ音響工学 的化誤盖簵囲と見做される微小な音圧增加であつてる， 刺战騒音の強さが $85 \mathrm{~dB}$ (ホン) 附近においては, 感覚 的に音の大きさが明らかに增大するし，また実際に NI-TTS を測定すると，全被検者に批いて急激な NITTS 值の增大のみならずその回復の延長，振巾縮小， 耳鳴音の金属化などが明らかに認められたのである、本 研究の实験方法およびこれらの結果について聴覚疲労現 象閶扵る従来の文献を参照して以下考察を加えて見た W.

1) 音刺战と NI-TTS：騒音刺韩強度を $2 \mathrm{~dB}$ step に微小增減せしめるような音響装置としての fine-step attenuator は，上述の椌差範囲が主な理由で現在のと ころ製作されていない（䋨音に関する茭圆は，製作され ている）、そこで，私達は同じ大きさ，同じ型をした受 話器（カプラ䄪 700cc）に吸音装置の材質やとりつ部 位を変党た 3 種類の受話器を用いることによつて, 省刺 战強度をほぼ $2 \mathrm{~dB}$ (phon) step に隇衰せしめることが できた，この方法はいつむ同じ周波数構成で同じ音正を すつて再生曝露せしめる点では好都合であるが, 各受話 器の周波数特性が第 1 図に示すように多小異なつてい るので，それが聴覚疲労代影響することが問題となる。 すなわら，各受話器の周波数特性曲線は，全体的には， 注近似しているのである。しかし，吸音装置のない $\mathrm{A}$ 受話器の周波数特性は 2 峰性カーブを示し $1000 \mathrm{cps}$ と6000cps 附近にピークを持ち、レシーバ (R-4号) を 薄い綿布で被覆したB受話器は $1000 \mathrm{cps}$ の及に最大の ピークがあり，それ以上の高音域のカーブは低下示し た.カブラ内壁をフェルトで覆つた $\mathrm{C}$ 受話器は, 約 $8000 \mathrm{cps}$ まで 1 octave-band $3 \mathrm{~dB}$ 位の上昇勾配を示す 特性を示し, この受話器の特性が騒音発生器出力の電気 的特生 (白色騷音) 飞最も類似している(第 1 図). 従 つて, 3つの受話器の中 B 受話器が $3000 \sim 6000$ cps の 高䇅レベルが他の受話器のそれに比べてかなり低いこ そを除いては，3つの受話器はほ湆類倾した周波数特性 を示している。，一般に，高音周波数成分は低音周波数成 分より聴覚に対して影響（疲労）をたし易いといわれ ている。例えば，Ward \$4) は，少くとも6000cps まで 快，周波数音が高まるにつれて TTSが增大するとい い, 特に各 band noise の間では 2400 4800cps, 1200 〜2400cps の音刺㦸で $4000 \mathrm{cps}$ の TTS が最大であつ
たと報告している。しかし，私達のこの砳究では，高音 周波数成分の比較的弱い $\mathrm{B}$ 受話器を 86 ホン話よび 81 ホンの音刺㦸用火，白色臨音の特性を示す $\mathrm{C}$ 受話器を 84 ホンと78 ホンの音刺軲に用いたが， B 受話器を用 いた時は C 受話器の時よりも常に NI-TTS が大き く, 結果的には冓受話器の周波数特性の相違に上る影響 は添とんど見られなからた。これは恐らく雨音の周波数 構成の高音周波数成分の差が軽度であつたために殊に高 音の影響を受けなからたものと推察される。

85 ホン附近の強度を選択したのは次の上うな理由に 上万、先つ第一に, Davis et al (19502) は純音110 130dB, 1 64 分, Rüedi and Furrer (1954 25)) は白 色騒音 130dB，1３2 分といらいずれも強大音響を人体 に嚗露しているが，これらの強度は，人体実騟としては

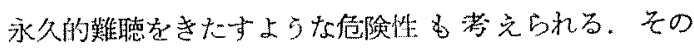
上，Davis が閶值の回復に数週を要すると述べている 上うに NI-TTS の回復性をみるのには余りに時間がか かり過焉ること，また音響刺战で強度の耳鳴が発生し， そのため検查音と混同をきたす恐れも多分にある等の 点が問題となる，彷つて，聴覚の動的な機能を把握しよ

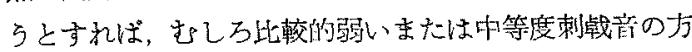
が適当であると考える．次に，第 2 の里明として，㴔力 保護の目的から騒音許容值の設定が古くから検討されて いるが, Kryter (1950) 14) 15), Ward 乱よび Glorig

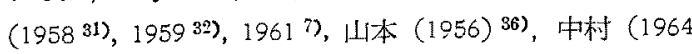
3ì)などの報告によれば，白色騒音の $85 \mathrm{~dB}$ (SPL または SL) の刺㦸強度が聴力の安全性からみた限界強 度であるとされている，以上のような理由に基つ゚いて本 研究ては特江耳の唄で 85 ホン前後の刺㦸強度の龭省 を用いた。

最近，騷音儤露之聴力損失との関係に打いて騒音周波 数構成々其仗暴露時阔が重要視されてきた。 Ward et

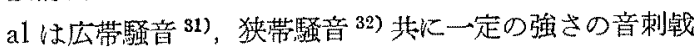
後 2 分目の NI-TTS は嚗露時间の対数に正比例すると 報告し，また中村 $(1864)^{37)}$ 《曝露音の强さが 60 85 $\mathrm{dB}$ SL があれば, NI-TTS は曝露時間の対数に対して

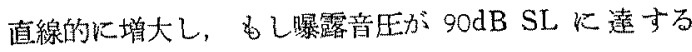
と NI-TTS と曝露時間の関係はむしろ濑近線の様相を 呈すると述べている. Schaefer (1960) ${ }^{26)}$ は，負荷時

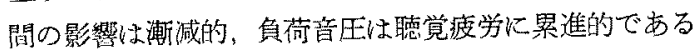
と記載している，短時間嚗露党行つた Lüscher and Zwislocki (1949) 18) の報告によれげ, NI-TTSは嚗露 時間に直線的な関係を示すといい，Ewing and Litter 
$(1953)^{5)}$, Hood (1950) ${ }^{12}$ ), Harris $(1953)^{8)}$, Davis et

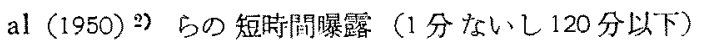

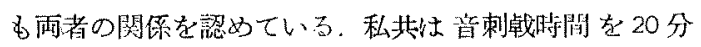

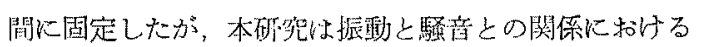

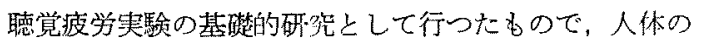
振動負荷耐容時䦩の都合で 20 分間曝露とした。

音刺战停止直後は閔值の変化が急澈であるので，initial NI-TTS の測定㑭始時間を一定にする必要がある. 本研究では装置の都合で刺战停止後閧值描記が開始され るまでには7〜10秒を要している. 刺战停止と同時に閶 值描記を行らことが望をしいが、これを正確に記録する ことは Békésy 型オージオメーターを用いてもなかな か困難であるといわれている，Ward (1957) 30) は負荷 停止後 2 分目の NI-TTS 值が儤露時間括よび回復率に 関数関係が成立するといい，束た，Ward (1962) およ び Bell and Fairbanks (1963) は，負荷停止後短特間 の休息時聞おいた方が停止直後から閣值描記を行うより も反つて NI-TTS の回復率がよく，検查音侍続音を 朋いるとこの傾向が影著汇現われると報告している。

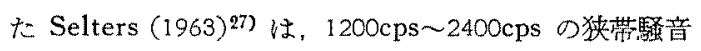
$82 \mathrm{~dB} \mathrm{SPL}$ D 50 秒刺㦸では，刺钱停止後 6 30 秒（R 6 3n) 内での NI-TTS の大きさは2分目の NI-TTS と一致するといい, 82dB 以下では R6 30 の NI-TTS は常に $2.5 \mathrm{~dB}$ となり, これは Hood (1950) 12) のいら per-stimulatory fatigue $の$ 影響加牫存 (warm-up effect）するためであるらと推定している。.上述のように ward らは音刺钱停止後数分程過した方が NI-TTS の growth p decay の関係がくみられるといらている が，刺軲停止 2 分後过りでは後述のよ5に bounce や 耳鳴が最も現われ易い時であり闍值が非常に不安定であ るので，中村などが述べているょらに刺战停此後の最值 測定開始はできる坮け早い力が回復様式を観察する上に る好都合である。

2) 79 ホンの音刺战強度と NI-TTS

本检查の No. 1, No. 7 の例が示寸如く79 ホンの刺 㦸では，NI-TTS はいずれも非常に小さいか任とんど 認められず，81 ホンの刺钱に強めると急激に NI-TTS が大きくなるのが見られた（第 4 図 A と B).79ホ ン剌㦸で NI-TTS がほとんど認められなからた事実 は非常に注目すべきことである，Reger and Liele

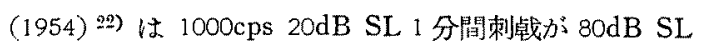
の刺㦸よりも NI-TTS が明らかル大きくなつたと報 告した，このよらな一見奇異と思われる現象について， その後検請を加之，1000cps $20 \mathrm{~dB}$ SL 刺战は感音性奞 聴耳においても正常耳と等しい NI-TTS 值を示したと のべ，かかる現象は，20dB SL 刺战では䦨值下㭘榃音 の影留似関与し，80dB SL では中耳㬳反射を起した NI-TTS が抑制せられたためであるらと推論している。 中村 (1964) 37) はこの現象は 1000cps のみならず 500 cps から $3000 \mathrm{cps}$ 附近の筙囲末で適用されるが $4000 \mathrm{cps}$ では適用されない，また懪露㭙間が1分よりも延長する につ机この現象は消失すると追加し，この現象の成立 には $80 \mathrm{~dB}$ SL 附近に閾值をすつ中耳筋の反射性収縮 が関与すると思われるとのべ Reger and Lierle の推 諭に支持を与学ている。变た Ward (1962) 34) 純音 と octave-band noise が同一音王であつて雨音が 2000 cps 以下であると, 騒音刺戦の方が聴器に対して危険性 が少ないと述へ，その原因は騷音刺战による中耳筋の reflex arousal (又射穴進) で内耳伝尊が抑制せられる ためであると推定し，また以上の Reger 現象は断続音 聴取ですみられ，特続音によつて一層よく観察されると 報告している，中耳梅反射については，Simons（1960）

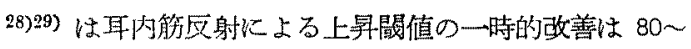
90dB の大きい音で短時間眿露した後にみられるといつ ている。市た，猫8匹を用いて 2000cps $135 \mathrm{~dB} 2$ 時間 連続懪露に対する中耳筋の音響外傷防筫機能を電気生理 学的に研究したところ, 螖牛障害の程度は中耳筋切断 群，中耳筋非活陲群 (全麻)，中耳筋正常群の順であつ たといら。また，Reger（1960）21) は大なる音压の高周 波数純音は低周波数音よりも中耳筋収縮の程度は弱く， 騠音とパルス音は大なる音王の增合のみ比較的大きい伝

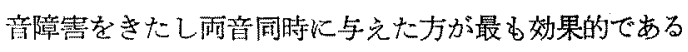
とい5. Ward (1962) 34) \&，低音性虽音は 2000cps 以上の高音性䂛音よりも中耳筋作用が高まることから， この㮦覚反射は低意性䮜音に上る㯖力損失抑制に重要な 役割をなしている強調した。しかし，一方，Flether et al (1960)6) は, 1000cps 98dB 20msec で予かじめ中

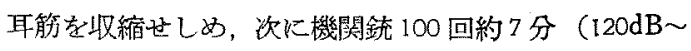
$132 \mathrm{~dB}$ ) 棰続射整後の NI-TTS を調ベた結果，24名中 17 名に $1000 \mathrm{cps}$ 以上の高密域で壮昫 $10 \mathrm{~dB}$, 最大 $50 \mathrm{~dB}$, の防貿效果がみられ，予想に反して低音域には中耳筋 の防蕉機能は認められなからたとのべている。しかし、 機関銃音心持続音さりさしろ断続音ないし㣫撃音に近

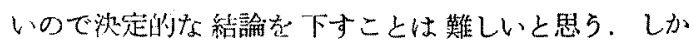
し, Dieroff (1962) 3) は衝慗音には中耳笳が関与しな いと報告しているように，持続性刺㦸音の時のような中 
耳笳反射が機関銃音の時でも起り得るかどらかについて は更涂討を加える必要があると考える。

以上の諸家の報告から，中耳筋反射は純音よりも虽音 K，その䮔音の中でも低音性騷音でしかも比較的強い刺 战て強く蕧起されることが分る。私達は，音刺㦸中およ び刺战後の鼓膜インピーダンスの変化を測定していない ので，これらの点を他覚的に実証し得なかつたが，夷験 の79ホン刺戱では NI-TTS がはとんど認められなか つた事は，恐らく中耳筋反射が元進して内耳伝学が抑湖 せられたためではないかと推定される。しかし，79 木 ンよりも僅か 2 ホンだけ音刺㦸を強めただけでる急激に NI-TTS が大きくなるので，もし79 ホン音刺战後の NI-TTS 抑制胃象に中耳筋反射説を適用す机ば，この 中聑筋反射はきかめて限られた強さの筋困内でしか関与 しないことが想像される、ところが，Trihipoe (1958) 34), Miller (1958) ${ }^{34)}$ および Ward (1962) 1) は stapes の振動様式の变化および中耳笳収縮のため $130 \mathrm{~dB}$ SPL は 125dB SPL よりも NI-TTS は小さいと報告 している，また比較的弱刺钱を用いた Bell and Fairbanks (1963)1) は同じ純音刺战でも 40dB SL と60dB SL では, 60dB SL 刺战の侍の方が NI-TTS の回復 が速いと述べている。

以上の諸家の報告に対して異なる意見をのべる矿究者 ઢいる. 例究ば, Hirsh and Bilger (1955) ${ }^{10}$ は刺战 音, 検査音は同じ周波数で 10〜80dB SL の間では NI -TTS の大きさは刺㦸音の強さには関原がなかつたとい W, Lawrence and Yantis (1957) ${ }^{16)}$ \&, $1000 \mathrm{cps}$ 60dB SL は 20dB SL よりも NI-TTS が大きく， $60 \mathrm{~dB}$ SL と 80dB SL の間には汪とんど差がなからた と報告している. 最近, Rodda (1962) 23) は NI-TTS の回復時間を指標として刺㦸音王との関係を゙観察し， 1000 2000cps 純音 1 分刺幟で $20 \sim 60 \mathrm{~dB}$ までは刺戟 音压の增加に従つて回復時間心延長 し，60 30dB の 間てはむしろ回復時間は短䈹し，80〜90dB では多分延 長すると述べ，4000～8000 cps 純音では刺㦸音圧の榰加 七回復時間は非加速度的延長を示し，とくに $4000 \mathrm{cps}$ を用いた時が最す回復時間が延長したと報告している。

私達の実験結果ては，音刺㦸の強さの增加に従つて NI-TTS の回復時間（音刺㦸前の悖關值にほぼ 復帰 し た時間）が延長するといら正此例的関係は必ずし女得ら れなからた（第 4 図 A と B) が，NI-TTS の大き岂 と回復時間とは関係があるようで，NI-TTS の大きい 場合柱知長り回復辩むよい結果を示した。
3） NI-TTS の回復過程：音刺战停止後連続して間

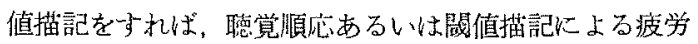
る加和つて刺㦸前の闌值になかなか回復しにくく，本た 場合に上つては回復の微候がまつたくみられないかある いは更に閶值上昇をきたすことさえ起ることがある。そ こで本実験では，刺战停止後 4 分間の遧続間值描記の後

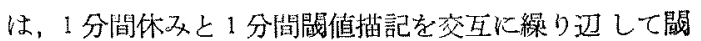
値の回復過程を20 分間㓋察した。 その結果，本実駼で は，NI-TTS の回復バーンは第 5 図に示す如く6䍿

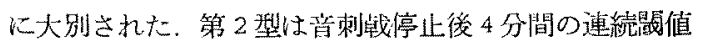
描記で，1952 年 Hirsh and Ward ${ }^{11)}$ によつて命名さ れた聴賞疲労の回復過程の逆転現象, 所謂 “bounce お よび facilitation あるい怡 sensitization”之思われる 2 相性あるい恃多相性の问復様相を示したものであつ て，この型を梁した都は全被倹者中 5 名であつた。

$こ の$ bounce 垷象住 Lightfoot (1955) $\left.{ }^{17}\right)$, Jerger (1956) ${ }^{13}$ ), Hinchcliffe (1957) $)^{9}$ らによつて砸究が重

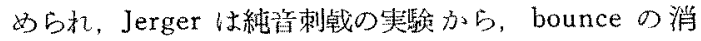

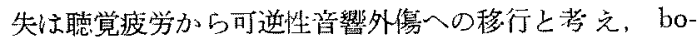
unce の消失する刺戱音の強さを重要視しいてる。 た, Hinchcliffe 估 octave band noise を用いて, む しろ, bounce の現われる時の制戟音の強度を重要視し ている. 中村 (1964) 37) はbounce が白色騒音 $85 \mathrm{~dB}$ SLに扣いて出現をしばしばみるのみならず，これと同 時に recruitment も現われはじめるといい， $35 \mathrm{~dB} よ$ り弱い騒音に上る聴覚疲労は生理的疲労, これを超杂て bounce の減少し始めてから消失する附近で抗こる疲 労は病的疲労と考克るべきでないかと考察している. Hirsh はその後 Bilger 上垬に (1955) ${ }^{10)}$ 恥賞疲労の 回復プロセスを $\mathrm{R}_{1}$ と $\mathrm{R}_{2}$ の2つに分け， $\mathrm{R}_{1}$ プロセス は回復が急速で bounce が出現し， $R_{2}$ は単調で旦つ緩 慢な回復過程を示し，前者の発来には，聴神絽與奮が， 後者见は毛細胞の化学区心五が関倸与るのであううと推定 している. また前述の $1000 \mathrm{cps}, 20 \mathrm{~dB}$ SL の NI-TTS の回復過程は $R_{2}$ と相応し， $80 d B$ SL のそれは， $R_{1}$ と $\mathrm{R}_{2}$ の結合プロセスであると述べている．Ward (1960) ${ }^{83)}$ は $\mathrm{R}_{1}, \mathrm{R}_{2}$ に詨して NI-TTS が 50dB にな るとその回復過程が非常に緩慢で完全回復には長時間を 要するといい，NI-TTS $50 \mathrm{~dB}$ ををすような音刺軲 强度が限界強度であるとして上述の回復ブロセスを $\mathrm{R}_{3}$ と呼んでいる、本実験でみら机た bounce 様現象は， 顕著な NI-TTS を示す音刺軲強度より1 step (2ホン) 弱い強さの時に出現し易いよらである，従つて，この絬 
果は上述の Jerger 括よび币村の bounce 現象出現に ついての見解に一致するるのである。他方，Hood (1950) ${ }^{12)}$ は NI-TTS の回復過程は monotonic process であるといい， Harris (1956) ${ }^{8)}$ は bounce の 出现は耳喑音によると報告している、私達は本研究とは 別飞聴賞疲労の回復過程を检查音に $4000 \mathrm{cps}$ 連続音と 断続音 (10ips そ 4ips, ips=interruption per second) の3種類を用いて同一人にないて比較桧討したが，断続 音 4ips の検祖望聴取によつて bounce 様現象が完全に 消失し, Hood のい5 monotonic pattern k示した。 従つて，bounce 現象は，断続音で完全消失することか ら，Harrisのいうような耳鴊音の增強のためかかた聴覚 順心現象で放るのかあるいは一㭙的な hyperacusis で あるのかその出現機棈については未だ不明な点が多い上 らに思市れる．更に今後の検討を待ちたい，

次に，N型とV型の回復様式法私澾の知る限りに拁い て未块知られていない様式と思れれる。即占，音刺战に よつて生じた閶値の上舁が刺戱前の閾値に一旦下降しな がら再び上犁し，そのまま闒值回復を示さない型（V 型）と闒值が回復㖽向を示しながら再び上梨し，年の後

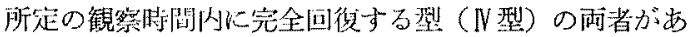

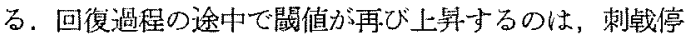
止後7〜9分目に起り易い上らである。これらの川型抽 よびV型が現われる时の NI-TTS 值はＩ型や【型の時 の NI-TTS 值よりも一般的に大きい，N型拉よびV型 は NI-TTS の大きさやその回復性加らみて回復洔間 のかかる型の棇行型に相当するものであるう。なお， 2 回目の閖値上昇時は 1 分問の閶値描記で最も閣值が上 算する傾问がある。興味のあることは，これらの2回目

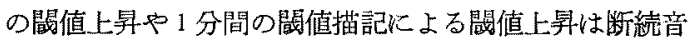
描記（4ips）で容易に消失することがある，多分これら の闒值上昇は聴覚順必現象であるいは毛細胞や聴神絽の 2 次的疲労によつて生じたものであるうと推察する。

本害䮖で音刺战に上る急激な NI-TTS や艺の回復の 藷时な延長は，僅か 2 ホン程度の刺㦸強度差で起り， そ の刺战強度は各被検者によつて相違することを明らかに 示した。

本項の初めに括いて述べたように本研究での実験装置 およびその方法に多くの問題が牫されているので，得ら れた実験結果に明確な結論を下すことは難しい，従つ て，今後更に実験装置に改良を加える（音刺战強度の表

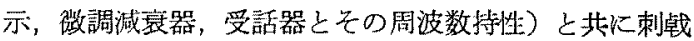
音，検査音，爆露時間，刺战強度㧍よび被検耳を色々と
変えて検討を重ねてゆきたい所存である。

\section{結論}

85 ホン前後の刺战騒度のレベルを恬 2 phon step に細分して，夫々の音刺㦸に上る $4000 \mathrm{cps}$ 純省聴閶值 の変化 (NI-TTS) を Békésy 型オージオメーターで 比較観察した．本実験対象者は現在まで数回この種の検 查を受けその検查を良く理解している正常聴力者9名で あつて，いずれも右側耳について観察された。その絬 果，次の結論を得た。

1）音刺战強度の差が僅か 2 ホン程度の差にもかか子 らず，NI-TTS の大きさに著明な变化を生ずるばかり

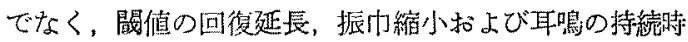
阔の延長や金属音化などの出兒が全被検者にみられた。 これらの裂化をきたす騒音の強さ被䧍者に上つて相違 した.

2）NI-TTS の回復過程を 20 分間観察したところ,

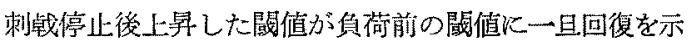
しながら刺㦸停止 7〜9分後で再び䦭値上昇するといら 回復過程をとるのがみられた。このような回復様相は著 明な NI-TTSをきたす 1 step 弱い音刺㦸で現われる ことが多い上らであつた。なお，この回復型は断続音 （4ips）を聴取せしめることによつて泀とんど消失する のが譛められた。

\section{䬸考文献}

1) Bell, D.W. and Fairbanks, G.: TTS produecd by low-level tones and the effects of testing on recovery, J. Acoust. Soc. Amer., 35; 1725, 1963. 2) Davis, H. et al.: Final report on temporary deafness following exposure to loud tones and noise, Acta Otolaryng., suppl. $88 ; 1950 . \quad$ 3) $\mathrm{Di}$ eroff, H.G.: Zur Problematik der Schlagimpulse im Industrielärm, Arch. f. Ohren usw., 179; 409, 1962. 4) van Dishoeck, H.A.E.: Masking fatigue, adaptation and recruitment as stimulation phenomena of the inner ear, Acta Otolaryng., 43; 167, 1953. 5) Ewing, A.W. and Littler, T.S.: Auditory fatigue and adaptation, Brit. J. of Psych., 25 ; 284, $1935 . \quad$ 6) Fletcher, J.L. et al.: Protective effect of the acoustic reflex for impulse noise, J. Acoust. Soc. Amer., 32; 401, $1960 . \quad$ 7) Glorig, A. et al.: Damage risk criteria and noise-induced hearing loss, Arch. of Otolaryng., 74; 413, 1961. 8) Harris, J.D.: Recovery curves and equinoxiosu 
exposures in reversible auditory fatigue following stimulation up to $140 \mathrm{~dB}$ plus, Laryngoscope, 63 ; 660, 1953. 9) Hinchcliffe, R.: Threshold changes at $4 \mathrm{kcps}$ produced bv bands of noise, Acta Otolaryng. 47; 496, 1957. 10) Hirsh, I.J. and Bilger, R.C.: Auditory-threshold recovery after exposures to pure tones, J. Acoust. Soc. Amer. 27; 1186, 1955. 11) Hirsh, J. and Ward, W.D.: Recovery of the auditory threshold after strong acoustic stimulation, J. Acoust. Soc. Amer., 24; 131, 1952. 12) Hood, J.D.: Studies in auditory fatigue and adaptation, Acta Otolaryng. Suppl. 92, 1951. 13) Jerger, J.F.: Recovery pattern from auditory fatigue, J. Speech Dis., 21 ; 39, 1956. 14) Kryter, K.D.: The effect of noise on man, J. Speech and hearing dis. Monograph Suppl. 1, 1950. 15) Kryter, K.D.: Noise safety criteria, Arch. Ind. Hyg. \& Occup. Med., 5; 117, $1952 . \quad 16)$ Lazerence, $M$. and Yantis, P.A.: Over-stimulation, fatigue, and onset of overload in the normal hearing ear, J. Acoust. Soc. Amer., 29; 265, 1957. 17) Lightfoot, $C$ : Contribution to the study of auditory fatigue, J. Acoust. Soc. Amer., 27; 356, 1955. 18) Lüscher, E. and Zwislocki, J.: Adaptation of the ear to sound stimuli, J. Acoust. Soc. Amer., 21 ; 135, 1949. 19) Munson, W.A. and Gardner, M.B.: Loudness patterns -a new approach, J. Acoust. Soc. Amer., 22; 177, 1950.20 ) Nixon, J.C. BA et al.: Predicting hearing loss from noise-induced TTS, Arch. of Otolaryng., 81; 250, 1965. 21) Reger, S.N.: Effect of middle ear muscle action on certain psychophysical measurements, Ann. of otol., 69; 1179, 1960.

Reger, S.N. and Lierle, D.M.: Chages in auditory acuity produced by low and medium intensity level exposures, Trans. Amer. Acad. Ophthal. Otolaryng., $58 ; 433,1954 . \quad 23)$ Rodda M.: Recovery from TTS, Acta Otolaryng., 55; 553, 1962. 24) Rüedi, L.: Different types of acoustic trauma by experimental exposure of the human and animal ear to pure tones and noise, Ann. of Otol., 63 ; 702, 1954. 25) Rüedi, L. and Furrer, W.: Different types and degrees of acoustic trauma by experimental exposure of the human and animal ear to pure and noise, Acta Otolaryng. 44; 502, 1954. 26) Schäfer, E.: Die Ermüdungsgrenze der Ohres, Zschr. f. Laryng, 39;556, $1960 . \quad 27$ ) Selters, $W$. Threshold recovery during the first thirty seconds, J. Auditory Research, 3; 1, 1963. 28) Simons, F.B.: Post-tetanic potentiation in the middle-earmuscle acoustic reflex, J. Acoust. Soc. Amer., 32; 1589, 1960. 29) Simons, F.B.: Middle ear muscle protection from the acoustic trauma of loud continuons sound. An. electrophysiological study in cats, Ann. or Otol., 69; 1063, 1960. Ward, W.D. et al.: Relation between recovery from TTS and duration of exposure, J. Acoust. Soc. Amer., 31 ; 600, 1957. 31) Ward, W.D. et al: Dependence of temporary threshold shift at $4 \mathrm{kc}$ on intensity and time, J. Acoust. Soc. Amer. 30; 944, 1958. 32) Ward, W.D. et al: Temporary threshold shift from octave band noise: Applications to damage-risk criteria, J. Acoust. Soc. Amer., 31; 522, 1959. 33) Ward, W.O.: Recovery from high values of temporary threshold shift, J. Acoust. Soc. Amer., 32; 497, 1960. 34) Ward, W.D.: Auditory fatigue and masking; Modern Developments in Audiology, Academic Press, New york, 1963. 35) Weber, E.G.: Theory of hearing; Wiley, new York；34）上り引用.

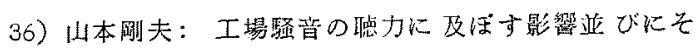
の周波数別恕限度，国民衙生，25:68，1956.

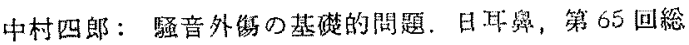

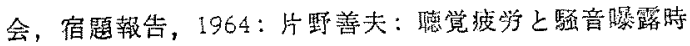

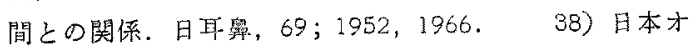
ージオロギー学会マスキングに関する委買会に㖞ける消 水修平氏の談話（京都，1965)。39）宮临一男：猚 音䑸折，5版，朝會害店，1965.

和を終るに当り，御校閲をいただた思的山本警

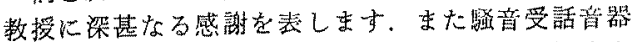
の周波数等性の測定に咕力を頂いた東神害策怢式会 社安淁博之氏に厚く御礼申し上げます。

本論交の要旨は，策 124 回大阪地方会（昭 $39.7 ）$, 第125回大阪地方会（昭39.9），第127回大阪地方 会 (昭40.2) 拈上び籍10回日本オージオロジー学 会総会（炤40.10）に和いて報告した。

（原程到着 $=$ 炤和 42.3 .15 日） 